\author{
Natalia Iwaszczuk \\ AGH University of Science and Technology \\ 30 Mickiewicza av., Krakow, 30-059, Poland, natalia.iwaszczuk@gmail.com \\ (D) https://orcid.org/0000-0002-7816-115X \\ Marta Szyba \\ AGH University of Science and Technology \\ 30 Mickiewicza av., Krakow, 30-059, Poland, marta.szyba@gmail.com \\ Aleksander Iwaszczuk \\ Cracow University of Technology \\ 24 Warszawska Str., Krakow, 31-155, Poland, aleksander.iwaszczuk@gmail.com \\ Valentyna Yakubiv \\ Vasyl Stefanyk, Precarpathian National University \\ 57 Shevchenko Str., Ivano-Frankivsk, 76018, Ukraine, yakubiv.valentyna@gmail.com \\ https://orcid.org/0000-0002-5412-3220
}

\title{
PRODUCTION OF AGRICULTURAL BIOGAS FROM WASTE - AN ELEMENT OF SOCIALLY RESPONSIBLE ACTIONS IN THE FOOD SECTOR
}

\begin{abstract}
The agricultural and food sector accounts for substantial volumes of organic waste (such as livestock excreta, meat offals) considered as onerous on the environment. The above decomposes formulating methane, carbon dioxide and hydrogen sulphide in anaerobic conditions. Methane produced in digester chambers of a biomass plant (called biogas) may be applied for the production of electricity and heat, powering of vehicles as well as injections into gas networks. Biogas is one of the renewable sources of energy. In the light of the EU's sustainable development and climate neutrality policies, increasing the share of renewable sources in overall energy consumption is a priority for the Member States. For this reason, the article examines one of the renewable energy sectors in Poland, which is agricultural biogas production. The main attention was focused on agricultural biogas plants. Most often used substrates for biogas production, the dependence of biogas plant location on the population living in particular regions (voivodships) and the development of agriculture in their territories were analysed. The main purpose of the article was to indicate the reasons for the failure of the agricultural biogas plant construction program in Poland. Literature and document analysis were performed, interviews with waste producers as well as owners of agricultural biogas plants were carried out, and SWOT analysis was prepared.
\end{abstract}

\section{Keywords}

renewable energy, organic waste, agri-food sector, agricultural biogas, biogas plants, SWOT analysis

\section{Introduction}

Statement that "decisions and actions undertaken by an organization always have an impact on the environment, regardless of the location of a given organization. Such impacts may be related to the use of resources, placement of organization actions, emission of pollutants as well as the impact of organization's activities on natural habitats" [1], draws reference to all human activities. Direct hazardous aspects of this activity include:

- emission of greenhouse gases (carbon dioxide, sulphur dioxide, nitrogen oxides, methane) and dusts into earth's atmosphere;

- discharges of waste water into surface waters;

- $\quad$ waste created in the course of production and consumption which constitute a secondary source of pollution emitted into the atmosphere and waters.

Carbon dioxide is deemed as being a particularly harmful gas, the content of which in the atmosphere continues to grow as a result of combustion of increasing volumes of fossil fuels. Since its share in increasing the earthly temperature is considered to be the largest of all (which leads to climate changes) actions are undertaken with the goal of decreasing its emission through processing power from renewable [2] and alternative sources. The

https://doi.org/10.32933/Actalnnovations.33.5 •ISSN 2300-5599 • (c) 2019 RIC Pro-Akademia - CC BY 
latter group encompasses biogas, obtained from waste treatment plants and landfills and produced by biogas plants from agricultural and food waste.

Substantial volumes of waste which subsequently turns into the potential source of pollution emitted into air and surface or ground waters are created within the food chain originating from agriculture and ending with consumption [3]. The majority of them may however be used in production of biogas called "agricultural biogas". China and India are the leading producers of this gas, using non-complex installations. Asia - Japan and South Korea and in Europe - Germany possess more advanced technologies for production of biogas and these particular countries indicate the most significant dynamics of growth in its production [4]. Biogas consists of a blend of methane, carbon dioxide, nitrogen and hydrogen sulphide, whilst the latter one must be eliminated prior to combustion in CHP units. It is possible to extract biogas from municipal water treatment plants, organized landfills (the so called landfill sites) and produce it in biogas plants. There are several types of biogas plants which, depending on the applied substrates, may be divided into: rendering, agricultural-rendering and agricultural [5]. The Act on Renewable Energy Sources (from 20 February 2015) [6] defines agricultural biogas as "fuel generated in the process of methane fermentation from agricultural raw materials, agricultural by-products, liquid or solid livestock effluents, by-products or residues from the processing of products of agricultural origin or forest biomass, with the exclusion of gas obtained from the raw materials generated by water treatment plants and landfills ". Agricultural biogas is generated by biogas plants formed by a complex of built structures adjusted to transforming the above specified raw materials (substrates) into biogas [7]. The substrates, as a result of the process of methane fermentation, are transformed into biogas (blend of: methane $40-85 \%$, carbon dioxide 16 $48 \%$ and nitrogen $0,6-7,5 \%)$ as well as digestate [8]. The obtained biogas, upon prior elimination of hydrogen sulphide, carbon dioxide and water vapor, is most frequently combusted in cogenerators as a result of which electricity and thermal energy are produced. The efficiency of cogeneration aggregates amounts to approx. $90 \%$ - electricity $40 \%$, whilst thermal energy - 50\%. Approx. $30 \%$ of thermal energy is used for sustaining the processes inside the bioreactor. Provided there are no major issues related to the sale of electricity, the sale of thermal energy is not at all times possible, which translates into a decreased investment profitability. Actions targeted at using biogas for vehicle powering [4] and injecting it to natural gas networks [5] are ongoing. The byproduct released in the course of biogas production from agricultural and food waste is digestate which, post drying and sterilizing, may be used as a high quality organic fertilizer.

The objective of the hereby article was to identify the reasons behind the failure to realize the programme specified within the document of the Council of Ministers [9] as well as to indicate actions which might accelerate its subsequent realization.

\section{Method}

The designated goal was achieved within the article through conducting a critical analysis of the subject literature as well as statistical data gathered from the National Support Centre for Agriculture (NSCA), Towarowa Giełda Energii (TGE) and Central Statistical Office (CSO). Direct interviews with the owners of agricultural biogas plants and landfills as well as the inhabitants, further to data obtained from the subject literature [10] and analysing legal regulations $[6,11,12]$ contributed to the conduct of SWOT analysis for agricultural biogas plants.

\section{Results}

Among the European countries the sector of agricultural biogas has acquired the most advanced form in Germany, where in 2018 as many as 9.5 thousand biogas plants were in operations [13]. In Poland, natural conditions are relatively alike in comparison to those experienced by our western neighbours and thus the development of biogas plant network would surely be a successful venture [2]. At present, our country holds 99 agricultural biogas plants (status as at 25.08.2019) which operate primarily on the basis of the German technology. Their total annual capacity equals $424739201 \mathrm{~m}^{3}$ of agricultural biogas, which constitutes less than $10 \%$ of its estimated potential (let us recall that the estimation amounted [9] to 5 billion $\mathrm{m}^{3}$ ). The total electric power of the installations in place equals 104,865 MWe [14].

Within the territory of Poland, agricultural biogas plants are unevenly scattered (compare table 1). The majority of biogas plants may be found in the following voivodeships: West Pomerania - 13, Greater Poland - 11, Lower Silesia - 10, Warmia-Masuria - 10, Podlaskie - 9, Pomerania - 9, whilst the least of them are located in: Świętokrzyskie - 1, Opolskie - 1, Lesser Poland - 2, Silesia - 2. Voivodeships with the largest number of this type of objects are distinguished by a substantially lower than average density of population (with the exception of Lower Silesia) and the location of ample larger agricultural farms which are involved in plant cultivation and 
farm animal breeding (caws, pigs, poultry) continuing the activity of former state-owned agricultural holdings from before 1990.

Table 1. Number of agricultural biogas plants in Poland divided into voivodeships

\begin{tabular}{|c|c|c|c|c|c|c|}
\hline \multirow[t]{2}{*}{ Voivodeship } & \multirow{2}{*}{$\begin{array}{l}\text { Population } \\
\text { density } \\
\text { [persons/ } \\
\mathrm{km}^{2} \text { ] }\end{array}$} & \multirow{2}{*}{$\begin{array}{l}\text { Number } \\
\text { of biogas } \\
\text { plants }\end{array}$} & \multicolumn{2}{|c|}{$\begin{array}{c}\text { Annual capacity } \\
\text { [Thousand } \mathrm{m}^{3} / \text { year] }\end{array}$} & \multicolumn{2}{|c|}{$\begin{array}{c}\text { Installed power } \\
{\left[\mathrm{MW}_{\mathrm{e}}\right]}\end{array}$} \\
\hline & & & Total & $\begin{array}{c}\text { Per } \\
\text { installation }\end{array}$ & Total & $\begin{array}{c}\text { Per } \\
\text { installation }\end{array}$ \\
\hline Lower Silesia & 146 & 10 & 34,491 & $3,449.1$ & 10.41 & 1.041 \\
\hline Kujawy-Pomerania & 116 & 6 & 29,679 & $4,946.5$ & 7.991 & 1.332 \\
\hline Lubelskie & 85 & 7 & 36,100 & $5,157.1$ & 9.859 & 1.408 \\
\hline Lubusz & 73 & 4 & 11,100 & $2,775.0$ & 2.792 & 0.698 \\
\hline Łódź & 137 & 4 & 21,913 & $5,478.2$ & 5.057 & 1.264 \\
\hline Lesser Poland & 222 & 2 & 20,946 & $10,473.0$ & 4.899 & 2.449 \\
\hline Masovia & 150 & 6 & 5,370 & $1,074.0$ & 1.150 & 0.230 \\
\hline Opole & 106 & 1 & 8,000 & $8,000.0$ & 2.000 & 2.000 \\
\hline Podkarpackie & 119 & 3 & 10,948 & $3,649.3$ & 2.498 & 0.833 \\
\hline Podlaskie & 59 & 9 & 31,458 & $3,495.3$ & 7.596 & 0.844 \\
\hline Pomerania & 126 & 9 & 47,968 & $5,329.7$ & 10.159 & 1.129 \\
\hline Silesia & 371 & 2 & 6,400 & $3,200.0$ & 1.596 & 0.798 \\
\hline Świętokrzyskie & 107 & 1 & 2,464 & $2,464.0$ & 0.800 & 0.800 \\
\hline Warmia-Masuria & 60 & 10 & 38,883 & $3,888.3$ & 8.464 & 0.846 \\
\hline Greater Poland & 117 & 11 & 38,253 & $3,477.5$ & 10.678 & 0.970 \\
\hline West Pomerania & 75 & 13 & 52,081 & $4,006.2$ & 11.690 & 0.899 \\
\hline
\end{tabular}

Source: Own elaboration based on the materials from the National Support Centre for Agriculture [11].

The most advantageous conditions for production of agricultural biogas from cow faeces have been reported in the following voivodeships: Greater Poland, Warmia-Masuria, Kujawy-Pomerania, Masovia and West Pomerania. On the other hand, with regards to production of biogas from pig faeces the most advantageous conditions have been noted in the following voivodeships: Greater Poland, Lower Silesia and Lubelskie, whilst in the case of poultry: Masovia, Greater Poland and Łódź. Thus, the most advantageous conditions for production of agricultural biogas from animal faeces may presently be found in Greater Poland Voivodeship which is on the second place when it comes to the number of agricultural biogas plants [15].

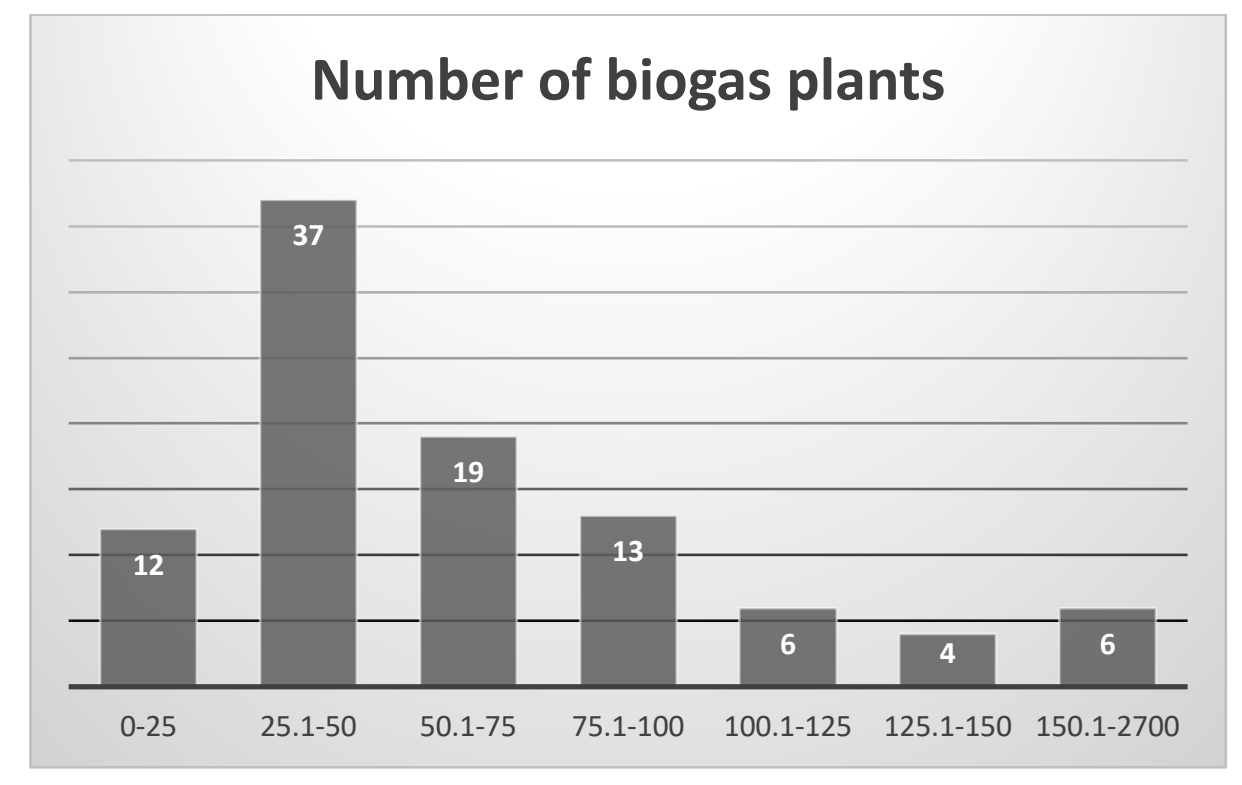

Figure 1. Dependence of the number of biogas plants on population density (persons $/ \mathrm{km}^{2}$ ) in municipalities Source: Own elaboration based on [11] 
Almost all agricultural biogas plants (81.83\%) are located in municipalities with population density below 100 persons $/ \mathrm{km}^{2}$ (compare Fig. 1), whilst the largest number of such objects (37.38\%) may be found in municipalities with population density between 25 and 50 persons $/ / \mathrm{km}^{2}$.

In Poland, agricultural biogas plants use organic waste as substrates $-73.65 \%$ (i.e. manure, slurry, chicken slurry, silage from grass and corn) and targeted cultivation $-26.35 \%$ (that is cultivated with a designation for production of electricity and/or thermal energy) [16). The most frequently encountered however are: slurry, fruit and vegetable leftovers, distillery grains and silage from corn [17]. Data concerning the use of individual fractions of waste in production of biogas in Poland (in the years 2011, 2013, 2016) have been presented in table 2.

Table 2. Raw materials used for production of agricultural biogas in the years 2011, 2013 and 2016

\begin{tabular}{|l|c|c|c|c|c|c|}
\hline \multirow{2}{*}{ Substrates } & \multicolumn{4}{c|}{ Years } \\
\cline { 2 - 6 } & \multicolumn{2}{|c|}{2011} & \multicolumn{2}{c|}{2013} & \multicolumn{2}{c|}{2016} \\
\cline { 2 - 6 } & $\begin{array}{c}\text { thousand } \\
\text { Mg }\end{array}$ & $\%$ & $\begin{array}{c}\text { thousand } \\
\text { Mg }\end{array}$ & $\%$ & thousand & Mg \\
\hline Slurry & 266 & 56.7 & 456 & 29.0 & 775 & 24.0 \\
Fruit and vegetable leftovers & 11 & 2.3 & 269 & 17.1 & 665 & 20.6 \\
distillery grains & 30 & 6.4 & 35 & 22.6 & 476 & 14.8 \\
Silage from corn & 109 & 23.2 & 287 & 18.2 & 439 & 13.6 \\
Marc & 7 & 1.5 & 102 & 6.5 & 222 & 6.9 \\
Technological sediments from agricultural & & & & & & \\
and food industry & 6 & 1.3 & 14 & 0.9 & 125 & 3.9 \\
Dairy industry waste & 2 & 0.4 & 13 & 0.8 & 89 & 2.8 \\
Manure & 12 & 2.6 & 30 & 1.9 & 86 & 2.7 \\
Green fodder & 13 & 2.8 & 2 & 0.1 & 5 & 1.8 \\
Waste biomass & 2 & 0.4 & 2 & 0.1 & 33 & 1.0 \\
Waste from food industry & 1 & 0.2 & 4 & 0.3 & 30 & 0.9 \\
Out of date foodstuffs & 0 & 0 & 0 & 0 & 29 & 0.9 \\
Other & 10 & 2.1 & 40 & 2.5 & 198 & 6.1 \\
\hline Total & 469 & 100 & 1574 & 100 & 3224 & 100 \\
\hline
\end{tabular}

Source: Own elaboration based on [18]

When analysing data presented in Table 2 one may conclude that with the continuous new appearances of biogas plants the mass of used substrates shifted (more than triple increase in the initial tested period, whilst in the second one - twofold) further to its percentage share. In 2011 slurry constituted more than half of the mass of used substrates, since out of 14 operating at the time biogas plants 8 belonged to the company Goodvalley Agro S.A. which owned large pig farms in Pomerania and West Pomerania Voivodeships. In the subsequent years the share of such substrates as fruit and vegetable leftovers, distillery grains and silage from corn escalated.

Between 2011 to 2016 the mass of organic waste used as substrates in domestic agricultural biogas plants increased almost 7 times (Table 2). The highest increase was observed in the case of fruit and vegetable residues (from 11,000 Mg to 665,000 Mg) and distillery waste (from 30,000 Mg to 476,000 Mg). Between 2011 and 2016, the amount of maize silage used for biogas production also increased from 109,0000 $\mathrm{Mg}$ to $439,000 \mathrm{Mg}$. This growth is at the expense of reducing the acreage of other crops and threatens to cause a shortage of forage as it happened in Germany [19].

The obtained information regarding agricultural biogas plants enabled the conduct of strategic analysis for the enterprise with the use of SWOT analysis (Strength, Weakness, Opportunities, Treatment), which has been presented in Table 3. It transpires that the strong sides of agricultural biogas plants include the possibility of using and utilizing waste produced by agricultural and food industry for production of biogas which may subsequently be applied for power supply purposes or as a fuel for powering vehicles. The digestate which is a by-product in production of biogas may be used as an organic fertilizer thus bringing financial benefits to owners of biogas plants and to the environment. 
Table 3. SWOT analysis of agricultural biogas plants in Poland

\begin{tabular}{|c|c|}
\hline Strong sides & Weak sides \\
\hline $\begin{array}{l}\text { - greater stability in electricity and thermal energy } \\
\text { supplies than in the case of other RES, such as for } \\
\text { instance: wind energy or solar energy, } \\
\text { - strongly developed agriculture and large volume } \\
\text { of agricultural and food waste, } \\
\text { - utilization of animal faeces preventing the } \\
\text { emission of methane to the atmosphere, } \\
\text { - decreased volumes of gathered waste of animal } \\
\text { and plant origin, } \\
\text { - cogeneration as an eco-friendly manner of } \\
\text { electricity and heat recovery from waste, } \\
\text { - digestate applied as high quality organic fertilizer, } \\
\text { - creating new work places for the local society. }\end{array}$ & $\begin{array}{l}\text { - lack of spatial management plans in the local } \\
\text { municipalities which would encompass the possibility } \\
\text { of locating construction area for a biogas plant, } \\
\text { - high investment costs, } \\
\text { - high power production costs when compared to other } \\
\text { RES, } \\
\text { - long-lasting process of arranging for permissions for } \\
\text { biogas plant construction, } \\
\text { - non-stability of law concerning RES and the power } \\
\text { market, } \\
\text { - lack of support on the side of the country, } \\
\text { - problem with managing heat in the period off the } \\
\text { heating season, } \\
\text { - resistance of the local community, } \\
\text { - odour nuisance, } \\
\text { - methane explosion hazard, } \\
\text { - the possibility of contamination of surface and ground } \\
\text { water in the event of a system breakdown, }\end{array}$ \\
\hline Chances & Threats \\
\hline $\begin{array}{l}\text { - favourable price of "blue certificates", } \\
\text { - EU energy policy focusing on obtaining energy } \\
\text { from RES, } \\
\text { - high fees paid by the producers from agricultural } \\
\text { and food sector for utilization of waste which } \\
\text { might constitute biogas plant's substrate, } \\
\text { - existence/construction of large food processing } \\
\text { plants in vicinity of a biogas plant, } \\
\text { - close vicinity of large animal farms such as cattle, } \\
\text { pigs, poultry, } \\
\text { - expansion of the local power grid, } \\
\text { - possibility of selling heat and gas, } \\
\text { - constantly growing demand for electricity. }\end{array}$ & $\begin{array}{l}\text { - drop in the prices of "blue certificates", } \\
\text { - volatility of prices of substrates originating from } \\
\text { power-targeted cultivations, } \\
\text { - drop in the prices for utilization of agricultural and } \\
\text { food waste, } \\
\text { - drop in the prices of conventional fuels, } \\
\text { - increase of land tax and property tax, } \\
\text { - shutdown of large food processing plant that provided } \\
\text { substrates for the biogas plant, } \\
\text { - animal epidemy causing entire herd culling, } \\
\text { - recurrent natural disasters (droughts, floods, } \\
\text { hailstorms, frosts, hurricanes etc.). }\end{array}$ \\
\hline
\end{tabular}

Source: Own elaboration 
The benefits stemming from biogas plants' operations can substantially overshadow the weaknesses of this type of investments. These include: high construction costs, long period of obtaining building permits, no local spatial development plans that would prevent the protests of local residents due to the unpleasant smell nuisance of this type of activity for residents.

The operation of a biogas plant can be associated with a methane explosion hazard that can cause human casualties and emissions of hydrogen sulfide, methane and carbon dioxide [20]. The unfavourable situation on the agricultural biogas plant market in Poland is also affected by the emerging threats resulting i.e. from the fall in prices of "blue certificates," utilization of waste and conventional fuels, the increase in taxes and the downturn of the agri-food industry. Fortunately, opportunities for improvement may appear, such as an increase in prices of "blue certificates" conducive to investment in the biogas market, EU energy policy geared to supporting this type of business, high costs and the obligation to dispose the waste in the agri-food industry.

The production of biogas used for electricity and heat production is not the only benefit of biogas plants. A byproduct of anaerobic methane fermentation is digestate used as a natural fertilizer in agriculture and horticulture, which has a positive effect on soil quality and contributes to an increase in the number of crops. What is more, grown plants have greater health properties, due to the appropriate content of macroelements (nitrogen, phosphorus, potassium) and microelements. At the same time, the number of nitrates and nitrites in agricultural products is reduced and cereals contain more B vitamins, carbohydrates and high-quality protein. The digestate has better nutritional properties than traditional slurry or manure, because plants better absorb the ingredients contained in the slurry after its fermentation. The use of digestate reduces the risk of groundwater contamination by nitrogen and phosphorus compounds, as it can occur when raw organic fertilizers (manure and slurry) are used. By using digestate as a fertilizer, we also avoid the risk of introducing pathogens and weed seeds into the soil [1].

The use of digestate as a fertilizer has another important advantage, which is the reduction of unpleasant odours associated with natural fertilizer dumps. The digestate is much less odorous than fermented liquid slurry or manure. When fertilizer, which is digestate, is intended for sale, it becomes a source of additional income for a biogas plant [2].

The most important advantage from the point of view of environmental protection is the production of fuel, the combustion of which causes zero balance of carbon dioxide emissions to the air. Methane contained in biogas comes from carbon dioxide taken from the atmosphere by plants during vegetation. Producing $1 \mathrm{MWh}$ of electricity from agricultural biogas also results in emissions of sulphur dioxide and nitrogen oxides into the air several times lower than in case of fossil fuels (mainly coal). Biogas plants, using organic matter for biogas production, limit its uncontrolled decomposition and thus reduce the emission of methane to the atmosphere [2].

\section{Discussion}

Biogas plants can be an important element of the national energy policy specified in the document, adopted on 10 November 2009 by the Council of Ministers, entitled "Polish energy policy until 2030" [12]. It assumes that in 2020 energy from renewable sources (RES) will have at least a 15\% share in final energy consumption (electricity, heat and cold). It also anticipates "a further increase in this indicator in subsequent years." What is more, it assumes a $10 \%$ share of renewable energy on the transport fuel market [5].

The EU is facing ever greater challenges for member states to achieve climate neutrality. In November 2016, the European Commission published its 'Clean Energy for all Europeans' initiative. As part of this package, the Commission adopted a legislative proposal for a recast of the Renewable Energy Directive. In the context of the co-decision procedure, a final compromise text among the EU institutions was agreed in June 2018. In December 2018, the revised renewable energy directive 2018/2001/EU entered into force [21].

Directive (EU) 2018/2001 of the European Parliament and of the Council of 11 December 2018 on the promotion of the use of energy from renewable sources, called RED II. "In RED II, the overall EU target for Renewable Energy Sources consumption by 2030 has been raised to $32 \%$. Within the $14 \%$ transport sub-target, there is a dedicated target for advanced biofuels produced from feedstocks listed in Part A of Annex IX. The contribution of advanced biofuels and biogas produced from the feedstock listed in Part A of Annex IX as a share of final consumption of energy in the transport sector shall be at least $0.2 \%$ in 2022, at least $1 \%$ in 2025 and at least $3.5 \%$ in 2030. Renewable electricity will count 4 times its energy content towards the $14 \%$ renewable energy in transport target 
when used in road vehicles, and 1.5 times when used in rail transport. The Commission will also develop a framework to guarantee that the renewable electricity used in transport is in addition to the baseline of renewable electricity generation in each Member State [21].

In December 2019, at the EU leaders' summit, the European Commission presented the main assumptions of the European Green Deal, which envisage further tightening of climate goals, including a reduction of greenhouse gas emissions by at least $50 \%$ till 2030. (formerly it was 40\%). To achieve this goal, the emissions trading system will be revised, as well as a new tax policy and climate law will be introduced. Investments in green innovation will increase. Supported by investments in green technologies, sustainable solutions and new businesses, the Green Deal can be a new EU growth strategy [22]. To achieve the presumed goals, EU countries must put more emphasis on renewable energy. Increasing biogas production (including agricultural biogas) in Poland may contribute to switching local power and heating plants to this energy source. This concept can be implemented mainly in rural areas, where agricultural production, culture (cultivation of crop plants, animal husbandry) and forest management are carried out. The estimated raw material potential in this type of areas in Poland was estimated in 2013 at the level of production of about 5 billion cubic metre of agricultural biogas annually with high-methane natural gas parameters [15].

Production of energy and heat in agricultural biogas plants would increase the country's energy security. Given the constantly increasing demand for energy, the construction of agricultural biogas plants in rural areas would be an antidote to the more frequent power outages caused by adverse weather conditions [7]. Situations of this type occur more often in Poland, even in the summer months, when the demand for electricity is often higher than in winter (related to the production of cold). In Polish conditions, agricultural biogas plants also have an advantage over wind or solar power plants due to the fact that energy derived from biomass and waste can be produced more evenly than from other RES. The only condition is to ensure the quality of the substrates. It is known that agriculture generates a very large amount of organic waste, which is a serious problem for farmers and communes. Waste that does not pose an epidemiological threat but has nutritional value can be processed into animal feed, fertilizer or used in other production processes. On the other hand, managing other waste poses many problems, as their disposal is often costly and time consuming. This applies especially to waste from gastronomy, agri-food production and slaughtering of animals. One of the possibilities of their management is using them as substrates in agricultural biogas plants. This is a particularly attractive perspective for producers who generate very large amounts of organic waste with high energy value. The use of this type of waste for the needs of biogas plants allows their utilization in an economically more advantageous way compared to traditional methods [23].

In Poland, according to the document adopted on 13 July 2010 by the Council of Ministers entitled "Directions for the development of agricultural biogas plants in Poland for the years 2010-2020" [5], it is possible to produce about 5 billion cubic metres of agricultural biogas. "The realistically available raw material potential for biogas production, contained in agricultural by-products and waste of the agri-food industry, is about 1.7 billion cubic metres per year" [9]. This would cover about $10 \%$ of the country's gas demand or $100 \%$ of the gas demand of rural consumers and produce additional amounts of electricity (estimated at around 125,000 MWhe per year) and heat (estimated at around 200,000) MWhe per year) [9].

According to the previously mentioned document, in 2020 one biogas plant is expected to operate on average in each commune [9]. Since there were 2,477 communes in Poland at the beginning of 2019, there should already be about 2,000 of them in the country (according to cautious estimates). Meanwhile, in 2018 biogas was produced only by 97 biogas plants, whose annual capacity was about 405 million cubic metres. The obtained biogas was burned in cogeneration aggregates producing electricity and heat, whose total installed electric power is about $102 \mathrm{MW}$ [11].

The state of development of agricultural biogas plants in Poland is related to the functioning of the operating support system for renewable energy sources. Until 2016, it was the so-called a system of certificates of origin (green certificates), as well as support for the production of heat energy in cogeneration in the form of "yellow certificates." The factor supporting the improvement of the situation on the biogas market was supposed to be the investment support mechanism in the form of subsidies and low-interest loans in the EU financial perspective 2007-2013. The value of subsidies granted was to be $30-70 \%$ of eligible costs at an average unit investment cost of 10-16 million PLN/MW [13].

https://doi.org/10.32933/Actalnnovations.33.5 • ISSN 2300-5599 • (C) 2019 RIC Pro-Akademia - CC BY 
The effect of favourable subsidies were investments in agricultural biogas plants with a capacity of 0.5-1.5 MWe, which in 2015 accounted for 55\% of all working installations. On the one hand, biogas plants of this size enable optimization of investment outlays, and on the other, maximization of revenues from green energy and certificates of origin. Larger biogas plants are built less often because of the complex logistics of raw material supply, as well as the potential impact on the environment and the associated risk of social protests [24].

The factor limiting the creation of agricultural biogas plants was the lack of prospects of stable conditions for the implementation of the investment, primarily in terms of the amount, length and form of financial support. The prices of renewable energy certificates of origin (so-called green certificates), listed on the Polish Power Exchange (TGE), also decreased. In the years 2011-2015, prices of certificates of origin dropped from PLN 280 to PLN 120. As a result, the biogas plant's revenues decreased from PLN 480 to PLN 300/MWh, which was the border price for profitability [24]. This, in turn, reduced the interest in investing in the biogas market, and those projects that had already begun to be implemented, were frozen at the initial stage. Commenced investments were suspended in order to be able to take advantage of the provisions in the new RES Act and clarification of the new auction system.

The Act of 29 December 2015 on renewable energy sources, called the Energy Law, introduced a distinction between energy certificates of origin, effective from 2016, depending on the source of its production. "Green certificates" are issued for energy generated from all renewable sources, except for agricultural biogas, for which the so-called "Blue certificates" have been introduced. They were more expensive than "Green certificates," as shown in Figure 2. This, combined with the modification of the auction system, increased the profitability of installations operating on the biogas market. This situation also encouraged potential investors who planned to build new biogas plants. If the adopted solutions are maintained, this is conducive to the development of the domestic energy sector. The introduction of a long-term solution, guaranteeing the maintenance of the purchase price of energy, produced from biogas (in Germany it is 20 years) should be considered [20].

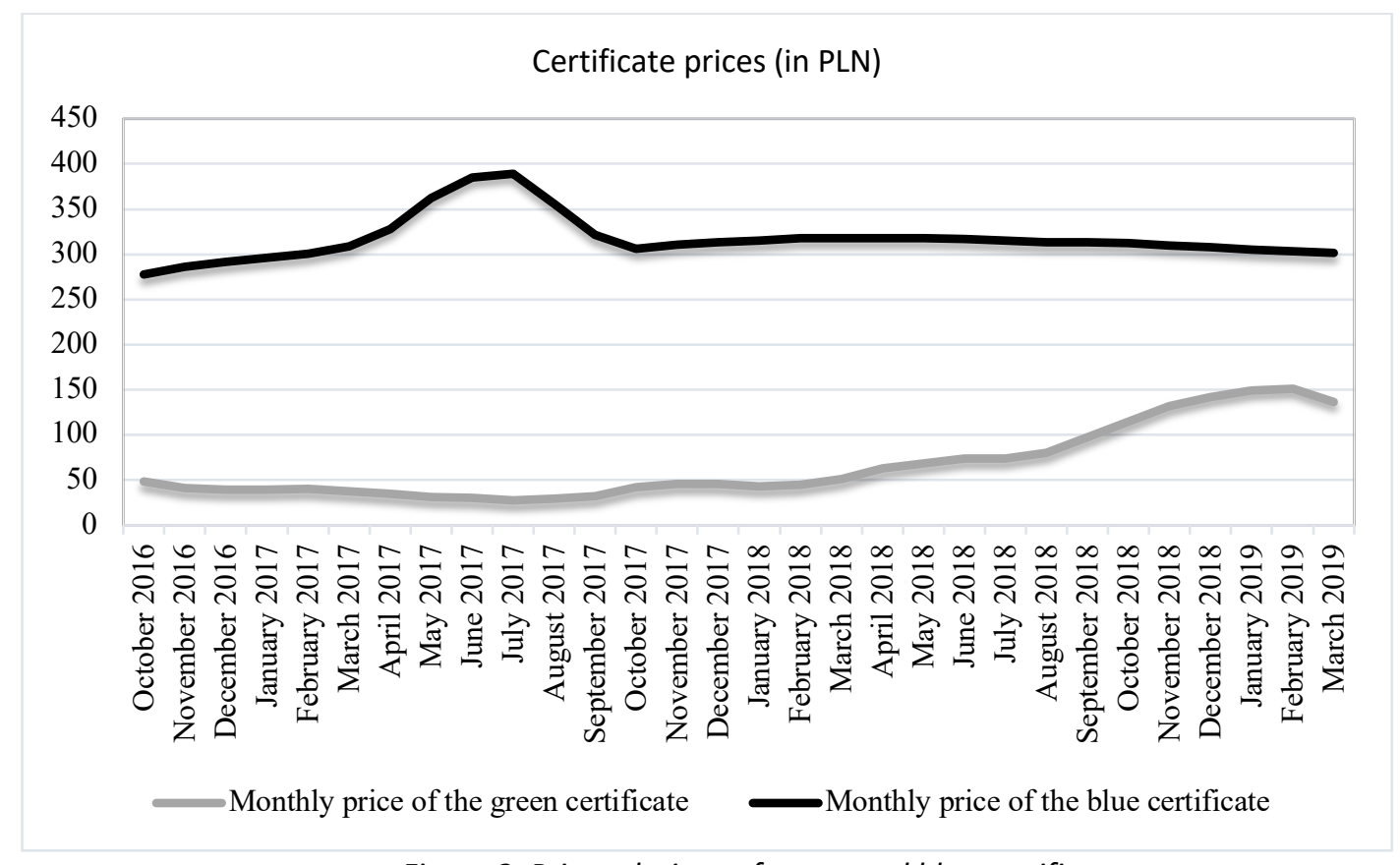

Figure 2. Price relations of green and blue certificates Source: [25]

Despite the above-mentioned favourable conditions for the sector, there are further barriers to its development. According to investors, the creation of biogas plants is hindered by the issue of permits, arrangements, opinions and other acts in the field of spatial planning and development, environmental protection, nature protection or building law that precede the construction process. The legal regulations related to the construction of biogas plants are the same as for the construction of other industrial plants and it seems that they should remain so. The functioning of biogas plants causes increased traffic of heavy vehicles and risk of road accidents, destruction of the road surface, increased exhaust emissions and, in the case of incomplete containment of the process, 
unpleasant smell. Pursuant to the Act of 22 June 2017 on access to information on the environment and its protection, public participation in environmental protection and environmental impact assessments, "biogas plants are investments that have the potential to significantly affect the environment." The introduction of more liberal regulations could cause even greater reluctance of rural residents, whose expected benefits, in the form of a market for their agricultural products or jobs, do not compensate for the inconvenience [7].

Therefore, it seems that a new approach to local spatial development plans in rural areas is needed. Communes should designate places for construction of biogas plants that are distant from areas designated for housing construction, which develops very quickly near cities. The observed process of urban population moving to the countryside means expanding of the areas excluded from food economy, which are associated with agricultural biogas plants, they cover up to $20 \mathrm{~km}$ of the area outside the borders of medium-sized cities and are much larger in the case of large agglomerations.

As for the use of digestate produced in biogas plants, placing it on the market as organic fertilizer is only possible after meeting the requirements set out in the Regulation of the Minister of Agriculture and Rural Development of 18 June 2008 on the implementation of certain provisions on fertilizers and fertilization (Journal of Law no. 119 , item 765). This regulation imposes an obligation to test organic fertilizers or plant conditioners for their suitability for fertilizing soils and plants. The digestate to be considered as a soil quality improvement agent must be tested in physio-chemical, chemical and microbiological terms. In Poland, this type of research is performed by voivodeship and poviat sanitary and epidemiological stations [26].

Uncertainty and impact of research results on science, economy, environment and society

The construction of biogas plants in Poland is associated with a number of difficulties, resulting primarily from uncertainty arising from the external environment. Risk factors may be of a macro (general economic) and mesoeconomic (industry) nature. Enterprises receive signals from the monetary and budgetary policies of the country implemented at a given time to what extent they may be guided by their own interests in their activities. Monetary policy affects: the level of interest on bank loans; the possibility of obtaining soft loans; obtaining of loan repayment guarantee etc. In favourable conditions, entrepreneurs can count on cheaper loans, and therefore the economy is developing, creating new products, new jobs and filling the budget with direct and indirect taxes. In turn, budget policy: shapes the amount and types of taxes paid; determines the tax relief and the direction and amount of transfer payments, including to support specific activities or develop specific territories (e.g. subsidies, investment grants, etc.). In addition, it is the state that is responsible for regulatory risk, as there is uncertainty about the ever-changing legal provisions. The assumptions adopted in the Document of the Council of Ministers "Directions for the development of agricultural biogas plants in Poland in the years 2010-2020" [9] have no chance of being implemented. Faster development of agricultural biogas plants in Poland would be possible if the legislator and the government introduced legal and financial facilitations for investors. Communes that would like to facilitate the construction of agricultural biogas plants for potential investors should find places in their local spatial development plans for their location. Such information should be made public to avoid a situation of issuing permits for the construction of residential houses in a biogas plant protection zone. This is very important because spatial development plans are adopted by communes and building permits are issued by Poviat Starosties.

In addition to economic risk, the investor is exposed to the risk of lack of social acceptance because people are often afraid of: unpleasant smell; heavy vehicle traffic; reducing the value of plots and real estate in a location close to the biogas plant. This may result in protests from the authorities and the local community. On the other hand, the already constructed biogas agricultural waste processing plant is exposed to ecological risk in the event of a breakdown and, consequently, increased costs and social dissatisfaction.

\section{Summary and conclusions}

The construction of an agricultural biogas plant has become a profitable investment after the introduction of "Blue certificates" in 2016. This revived the industry and appeased biogas plant owners, who were often on the verge of bankruptcy before implementing these regulations. An agricultural biogas plant can also profit from the sale of digestate as an organic fertilizer, which is a good alternative to traditional fertilizers and can attract interest of local farmers. It is also beneficial for breeders of slaughter animals, slaughterhouses and the food industry, as they will incur lower costs of waste disposal. In many cases, they are limited only to the cost of transporting waste to the biogas plant.

https://doi.org/10.32933/Actalnnovations.33.5 • ISSN 2300-5599 • C 2019 RIC Pro-Akademia - CC BY 
Based on the analysis of the literature and interviews, a SWOT analysis of the construction of a biogas plant has been carried out.

Its results made it possible to indicate the following main reasons for low implementation of biogas policy in Poland:

- lack of a comprehensive government support program for the construction of agricultural biogas plants including a program of subsidies, low-interest loans and a long-term program of guaranteed electricity prices;

- $\quad$ existing subsidies, unfortunately, are granted only in the case of construction of small agricultural biogas plants (with a capacity of 0.5-1.5 MWe), which causes their large dispersion in the territory of the country;

- a large number of small biogas plants creates logistical problems related to the supply of substrates to many different places and additional costs (financial and environmental) on a national scale,

- a large number of small, low-power biogas plants are associated with an additional negative impact of their activities on society and the environment;

- the lack of long-term local spatial development plans in most communes means that the existing singlefamily houses turn out to be in the "impact zone", which causes social opposition to the construction of a biogas plant.

Despite many problems and barriers, there is a good chance for further development of this sector in Poland. Many potential investors see a number of benefits in building agricultural biogas plants. However, they are deterred by excessive bureaucracy, high construction costs and a long investment period. The data presented in the Bio Alians database shows that in 2016 there were 570 agricultural biogas plant projects, 95 of which were already existing installations. The database includes 475 agricultural biogas plants projects at various stages of completion with a total planned capacity of 570 MWe. A positive environmental decision was issued for 243 projects [27]. This means that the potential for building agricultural biogas plants in Poland is high and a change in legal regulations to more favourable and larger government subsidies would contribute to the development of the domestic biogas energy sector.

\section{References}

[1] A. Łagocka et al., Korzyści ekologiczne ze stosowania pofermentu z biogazowni rolniczych jako nawozu organicznego, Kosmos 65(4) (2016) 601-607.

[2] E. Obrycka, Korzyści społeczne i ekonomiczne budowy biogazowi rolniczych, ZN SGGW, Ekonomika i Organizacja Gospodarki Żywnościowej 107 (2014) 163-176.

[3] N. Iwaszczuk, M. Szyba, Rzetelna informacja o produktach głównym elementem polityki społecznej odpowiedzialności przedsiębiorstw łańcucha żywnościowego, Problemy Jakości 9 (2016) 20-27.

[4] R. Pomykała, P. Łyko, Biogaz z odpadów (bio) paliwem dla transportu - bariery i perspektywy, Chemik 67(5) (2013) 454-461.

[5] M. Owczuk et al., Wykorzystanie odpadów biodegradowalnych do produkcji biogazu jako alternatywnego źródła energii odnawialnej, Studia Ecologiae et Bioethicae UKSW 11(3) (2013) 133-144.

[6] http://isap.sejm.gov.pl/isap.nsf/download.xsp/WDU20150000478/U/D20150478Lj.pdf (access on 05.03.2019)

[7] A. Ostrowska, Prawno-administracyjne bariery budowy biogazowni rolniczych w Polsce, Acta Universitatis Lodziensis - Folia Oeconomica 270 (2012) 127-135.

[8] Biogaz rolniczy odnawialne źródło energii - teoria i praktyczne zastosowanie, W. Podkówka (ed.), Powszechne Wydawnictwo Rolnicze i Leśne, Warszawa, 2012.

[9] Document of the Council of Ministers, Kierunki rozwoju biogazowi rolniczych w Polsce w latach 20102020, Warszawa 2010.

[10] B. Igliński, R. Buczkowski, M. Cichosz, Biogazownie rolnicze w Polsce - stan aktualny, potencjał, analiza SWOT, Rynek energii 3(118) (2015) 93-101.

[11] https://www.premier.gov.pl/wydarzenia/decyzje-rzadu/kierunki-rozwoju-biogazowni-rolniczych-wpolsce-w-latach-2010-2020.html (access on 05.03.2019)

[12] http://prawo.sejm.gov.pl/isap.nsf/download.xsp/WDU20150002365/T/D20152365L.pdf (access on 05.03.2019)

[13] A. Piwowar, M. Dzikuć, Charakterystyka podmiotów zajmujących się wytwarzaniem biogazu rolniczego w Polsce, Journal of Agrobusiness and Rural Development 1(27) (2013) 207-217. 
[14] http://www.kowr.gov.pl/odnawialne-zrodla-energii/biogaz-rolniczy/wytworcy-biogazu-rolniczego (access on 05.03.2019, 4.09.2019)

[15] M. Jasiulewicz, D.A. Janiszewska, Potencjalne możliwości rozwoju biogazowni na przykładzie województwa zachodniopomorskiego, Inżynieria rolnicza 2(143) (2013) 91-102.

[16] J. Chodkowska-Miszczuk, D. Szymańska, Agricultural biogas plants-A chance for diversification of agriculture in Poland, Renewable and Sustainable Energy Reviews 20 (2013) 514-518.

[17] A. Jędrejek, Z. Jarosz, Regionalne możliwości produkcji biogazu rolniczego, Roczniki Naukowe Stowarzyszenia Ekonomistów Rolnictwa i Agrobiznesu 18(6) (2016) 61-66.

[18] P. Gradziuk, Potencjał i prognozy wykorzystania biogazu rolniczego w Polsce, Roczniki Naukowe Stowarzyszenia Ekonomistów Rolnictwa i Agrobiznesu, Vol. 19 (3) (2017) 64-70.

[19] S. Theurel S. et.al., The future agricultural biogas plant In Germany: A Visio, Energies, 12(3) (2019) 1-32.

[20] I. Daniel-Gromke et al., Current developments In production and utilization of biogas and biomethane in Germany, Chemie Ingenieur Technik, 90(1-2) (2018) 17-35.

[21] https://ec.europa.eu/jrc/en/jec/renewable-energy-recast-2030-red-ii

[22] https://ec.europa.eu/info/strategy/priorities-2019-2024/european-green-deal_en

[23] A. Curkowski, A. Oniszk-Popławska, A. Haładyj, Biogazownia - przemyślany wybór. Co powinien wiedzieć każdy obywatel, Fundacja instytutu na rzecz Ekorozwoju, Warszawa, 2013.

[24] A. Curkowski, Rynek i perspektywy rozwoju biogazowni rolniczych, Czysta energia 2 (2016) 22-25.

[25] https://tge.pl/pl/536/ceny-okresowe-oze (access on 23.02.2019)

[26] A. Kowalczyk-Juśko, Wykorzystanie masy pofermentacyjnej - krok po kroku, Czysta Energia 3 (2014) 3840.

[27] https://globenergia.pl/w-ciagu-4-lat-powinno-powstac-700-800-biogazowni-rolniczych/ (access on 05.03.2019) 